\title{
Development of Pop Up Book Media Material Distinguishing Characteristics of Healthy and Unfit Environments Class III Students Elementary School
}

\author{
Erwin Putera Permana $1^{*}$, Yeny Endah Purnama Sari²
}

1,2 PGSD Departement, Universitas Nusantara PGRI Kediri , Indonesia

\section{A R TICLEINFO \\ Article history: \\ Received 15 Desember 2017 \\ Received in revised form 28 Desember 2017 \\ Accepted 17 Januari 2018 \\ Available online 20 \\ Februari 2018}

Kata Kunci:

Media Buku Pop Up

Lingkungan Sehat dan

Tidak Sehat

Keywords:

Pop Up Book Media,

Healthy And Unhealthy

Environment

\section{A B S T R A K}

Penelitian ini didasarkan pada pengamatan di kelas III IPA materi lingkungan yang sehat dan karakteristik lingkungan yang tidak sehat, bahwa sebagian besar siswa mengalami kesulitan dalam pembelajaran karena guru menggunakan metode pengajaran konvensional. Selain itu, penggunaan media pembelajaran dianggap kurang maksimal oleh guru. Penelitian ini merupakan penelitian dan pengembangan ( $R$ \& D) dengan model pengembangan ADDIE. Tahapan ada 5 tahapan yaitu 1) Analisis (Analisis), Pengembangan (Desain), Implementasi (Implementasi), Evaluasi (Evaluasi). Validasi dilakukan oleh ahli materi, ahli media, dan guru kelas. Kesimpulan dari penelitian ini adalah (1) Hasil pengembangan media Pop Up Book dengan materi untuk membedakan karakteristik lingkungan sehat dan tidak sehat Valid. (2) Respon guru terhadap media pembelajaran Pop Up Book yang dikembangkan, setelah digunakan dalam pembelajaran materi, karakteristik lingkungan yang sehat dan tidak sehat memperoleh respon yang baik. Demikian juga respon siswa terhadap media ini mendapat respon positif. (3) Pop Up Book media karakteristik lingkungan yang sehat dan tidak sehat berdasarkan penilaian keseluruhan dari persentase penilaian berada dalam kategori sangat tepat untuk digunakan sebagai media pembelajaran IPA untuk siswa kelas 3 SD. Berdasarkan kesimpulan penelitian ini, direkomendasikan: (1) untuk guru, salah satu media yang dapat digunakan dalam mendukung proses pembelajaran adalah Pop Up Book, dapat membantu siswa menjadi lebih aktif dan dapat menciptakan suasana kelas yang menyenangkan. (2) Untuk penelitian lebih lanjut, uji coba harus dilakukan lebih luas, sehingga menghasilkan media pembelajaran yang banyak digunakan.

A B S T R A C T

This research is based on the observation in the third grade of Natural Science (IPA) subject matter of healthy and unhealthy environment characteristic, that most of students have difficulty in learning because the teacher uses conventional teaching method. In addition, the use of learning media is considered less maximized by teachers. This research is research and development (R \& D) with model of ADDIE development. Stages there are 5 stages namely 1) Analysis (Analysis), Development (Design), Implementation (Implementation), Evaluation (Evaluation). Validation is done by material experts, media experts, and classroom teachers. The conclusion of this research is (1) Result of Development of Pop Up Book media with material to distinguish the characteristics of healthy and unhealthy environment Valid. (2) The teacher's response to the learning media of Pop Up Book that was developed, after being used in learning material, characteristic of healthy and unhealthy environment obtained good response. Likewise the response of students to this media get a positive response. (3) Pop Up Book media characteristics of a healthy and unhealthy environment based on the overall assessment of the percentage of assessment is in the category of very appropriate to be used as a medium of learning Natural Science for grade 3 primary school students. Based on the conclusions of this study, recommended: (1) for teachers, one of the media that can be used in supporting the learning process is Pop Up Book, can help students become more active and can create a fun class atmosphere. (2) For further research, trials should be conducted more widely, so as to produce a widely used learning medium.

Copyright (C) Universitas Pendidikan Ganesha. All rights reserved.

\footnotetext{
${ }^{1}$ Corresponding author.

E-mail addresses: erwinp@unpkediri.ac.id (Erwin Putera Permana)
} 



\section{Introduction}

Education is a conscious and well-planned effort to create an atmosphere of learning and learning process so that students actively develop their potential to have spiritual, religious, self-control, personality, intelligence, noble character and skills needed by themselves, society, nation and nation (Permana, 2015: 2). Knowledge in everyday life, human beings can not be separated from the science of nature. This includes learning science (Natural Science). Humans gain knowledge and experience about interactions with living things, as well as natural phenomena including the environment in which we live.

Haryono (2013: 64), Natural Science Learning can be experienced in daily life, whenever and wherever one can encounter the phenomenon of natural science including the environment in which we live. Based on the statement of some experts above it can be concluded that education and learning science is the potential development of activities carried out daily, whenever and wherever humans, especially elementary school students.

Natural Science learning process is expected students can use the environment as a source of learning science of nature. Haryono (2013: 65) states that the benefits to be gained when we use the environment as a learning resource are: 1) learners are informed by direct experience, therefore teaching will be more meaningful and interesting; 2) the application of science in everyday life becomes easier and in accordance with the problems faced by learners; 3 ) according to the principles of education, that learning must start from the: concrete to the abstract, easy / simple to the difficult / complex, and already known to the unknown.

Giving understanding of the concept and theory to learners, then learners can gain meaningful experience directly. Meaningful means during the learning process takes place, students not only memorize the concept or theory but do activities that connect the concepts to produce a complete understanding so that the concepts learned will be understood well, and awareness of the environment that can be applied in everyday life.

Learning objectives can be done well, then in the process of learning required the existence of guidelines to help teachers in planning the learning process is by referring to the curriculum. In the curriculum has been listed competencies that must be achieved in the learning process. One of the basic competencies to be achieved in the third grade of elementary school is to distinguish features of healthy and unhealthy environments based on observations. Achieving the basic teaching competence then teachers need to develop some indicators. the indicators are described as follows: 1) explain the definition of the environment, 2) mention the characteristics of a healthy environment, 3) mention the characteristics of unhealthy environment, 3) distinguish the unhealthy environment conditions. Thus the students can explain the characteristics of a healthy environment, explain the characteristics of a less healthy environment, and compare the condition of the less healthy environment.

In fact, the third grade students lack the understanding of distinguishing features of healthy and unhealthy environments. Based on preliminary studies conducted in elementary school (SD), there are students who complain that science learning is boring and difficult. This is because the teacher is less creative in using learning media and other supporting devices, the problem resulted in student learning outcomes in science lessons, especially the mastery of healthy and unhealthy environmental materials less than optimal. Therefore, the use of learning media in the learning process is needed to build students' understanding.

Ideally, the science-learning process in elementary school provides an opportunity for students to play an active role in the learning process through real learning activities that can cultivate students' curiosity and scientific attitude. The scientific attitude of students in the process of science learning can be developed through discussion, experiment, simulation, or project activities in the field (Susanto, 2013: 169). Interesting science lessons are not just knowledge of facts, concepts, and theories, but meaningful learning so as to stimulate students' curiosity about their learning and environment.

Problems based on the above description can be concluded that to overcome these problems need to be developed appropriate learning media to assist in the learning process of healthy and unhealthy environment. One of the right media to be developed in the learning process is the pop-up book media.

The use of pop up book media as a medium of learning environmentally healthy and unhealthy material is very relevant. This is because the learning of Natural Sciences contains a lot of abstract concepts. By using pop-up book media, students will more easily understand the material features of a healthy and unhealthy environment, because this pop-up book media will facilitate students in distinguishing features of healthy and unhealthy environment. 


\section{Methods}

The development used in this research is using research and development method. Sugiyono (2012: 297) said, "research and development method is a research method used to produce a certain product and test the effectiveness of the product. In line with Sugiyono, Mulyatiningsih (2011: 145) "research and development aims to produce new products through the development process. Based on the above description can be concluded that research and development is research that aims to produce new products and test the effectiveness of these products.

According to Mulyatiningsih (2011), there are 3 types of research and development, namely Borg \& Gall, 4D, and ADDIE (Analysis, Design, Development, Implementation and Evaluations). In this research and development paper, developers use the ADDIE model. This development procedure adapts from the steps of the ADDIE development model, a development model consisting of five stages: Analysis, design, development, implementation, evaluation. 1) Analysis, a. Needs analysis that includes the needs and characteristics of students who will become target users pop up book. b. Competency and intuksional analysis that includes analysis of Competency Standards and Basic Competencies that will be published in this media. Competency Standards to be published are Understanding environmental conditions that affect health, and efforts to maintain environmental health. Instructional analysis is an elaboration of Basic Competencies that have been selected at the competency analysis stage into a learning indicator that allows to be presented in a pop up book. 2) Design, a. Based on the results of the analysis, the next stage is done stage design or product design that includes: a. Media Design, The first step is to fold the paperboard into two parts and sketch the shapes and drawings using the manual technique using a pencil. Then do the staining and cutting process using scissors or cutter. After that, the pieces are arranged on cardboard with glue and double tape. And then the last step is to do binding by combining between pages. b. Setting Material, At this stage the basic election of natural science subjects on discriminating the characteristics of healthy and unhealthy environment. Natural science is chosen because it corresponds to the author's competence. In addition, there are difficulties in the lack of use of instructional media and many teachers are still using conventional methods or lectures in teaching science. c.Preparation of Problems and Answers, Problems and discussion that will be published in this media is a material about the characteristics of a healthy and unhealthy environment based on observations. Preparation of materials, problems, and discussion in this media is made from various references.d. Assessing Subjects Subject to Curriculum, Competency Standards understand environmental conditions that affect health, and efforts to maintain environmental health with Basic Competencies Distinguish features of healthy environments and unhealthy environments based on observed observations in accordance with current school curriculum guidelines. 3) Development, a.Creating Learning Media Product Pop Up , At this stage the learning media products are made in accordance with the predetermined technique of using Transformations, Peepshow, and Pull-tabs. b. Expert Content and Media Expert Validation, The validation process is done by material experts and media experts. The results are comments / suggestions and inputs that can be used as a basis for revision of developed media and as a basis for product testing on students. 4) Implementation, This implementation phase, the product will be tested to 24 students of SDN Mojoroto 2 and 29 students of SDN Burengan 2. At this stage also distributed questionnaires to measure and know the opinion or the response of learners about the learning media pop up book for the study of Natural Sciences (IPA) material features of a healthy and unhealthy environment. If necessary it will be revised based on comments or suggestions from learners. However, in this revision will be considered comments or suggestions from previous validators so as not to conflict with previous improvements.. 5) Evaluation, From the test phase obtained the assessment and response from the questionnaire given to teachers and students as well as test results given to students. Questionnaires and test results will be analyzed to determine the effectiveness of the media. The results of this analysis are used as a reference of whether or not the final product revision.

The product trial intends to collect data that can be used as a basis for determining the effectiveness, efficiency and / or attractiveness of the resulting product. The section includes 1) the design of the trial, and 2) the test subjects. a. Test design, Learning media product pop up book needs to be tested to know the quality and feasibility. The product test is part of a series of validation and evaluation steps. The products will be consulted to lecturers, lecturers, media experts, teachers and elementary students as potential users of the product. Here are the steps in the validation and evaluation steps: 1) Prevalidation, The researcher conducts consultations on the products that have been prepared to supervisor lecturer. The purpose of this step is to get feedback, suggestion and suggestion from the supervisor about the quality of the media before validation. 2) Expert Validation, At this stage the validator validates the product to perform evaluation and revision based on suggestions or comments to 
know the product deficiencies. Validator assess the feasibility of the product in terms of four components of material aspects, images, neatness, appearance and media design. In addition, the teacher also becomes a validator who will assess all components of product feasibility. And student opinions are also used as input to improve the product. A) Test Subject, The subjects of instructional media of Pop Up Book are conducted by learning media expert, material expert, third grade teacher of SDN Mojoroto 2 with 24 students and teacher III SDN Burengan 2 with 29 students..

Permana (2015: 137) states that the feasibility of the product is done by devising an assessment instrument to be given to media experts, designers of instructional media, teachers and students. The results of this instrument will serve as guidelines for the improvement of learning media products. The data collection instrument used in this research is a questionnaire about the feasibility of learning media. The questionnaire is made for material experts, media experts, teachers and students of class III with different questionnaires in accordance with their respective functions and interests.

Questionnaires in the use of validators to mengetauhi media is feasible or not to be tested. The results of a validated questionnaire can be used to find out which media needs to be evaluated or revised. Thus if in the questionnaire there are suggestions or suggestions that can be made to improve the product, then the suggestion will be reconsidered to make the product even better.

\section{Result and Disscusion}

Here are the results of research, namely there are: Media specifications, media principles, Media advantages, and Weakness Media.

1. Media Specification

The media is made of cardboard lined with flannel. The media is made by folding the cardboard into two parts and binding the cardboard with the duct tape. Paint or coloring that is used to color the media using paint crayons and markers. Posts and numbers that exist on the media in the design with a variety of colors to attract. The use of glue used in this medium is to use a candle glue and douple type. The design development of pop up book media as follows.

Tabel 1. Pop up book media design

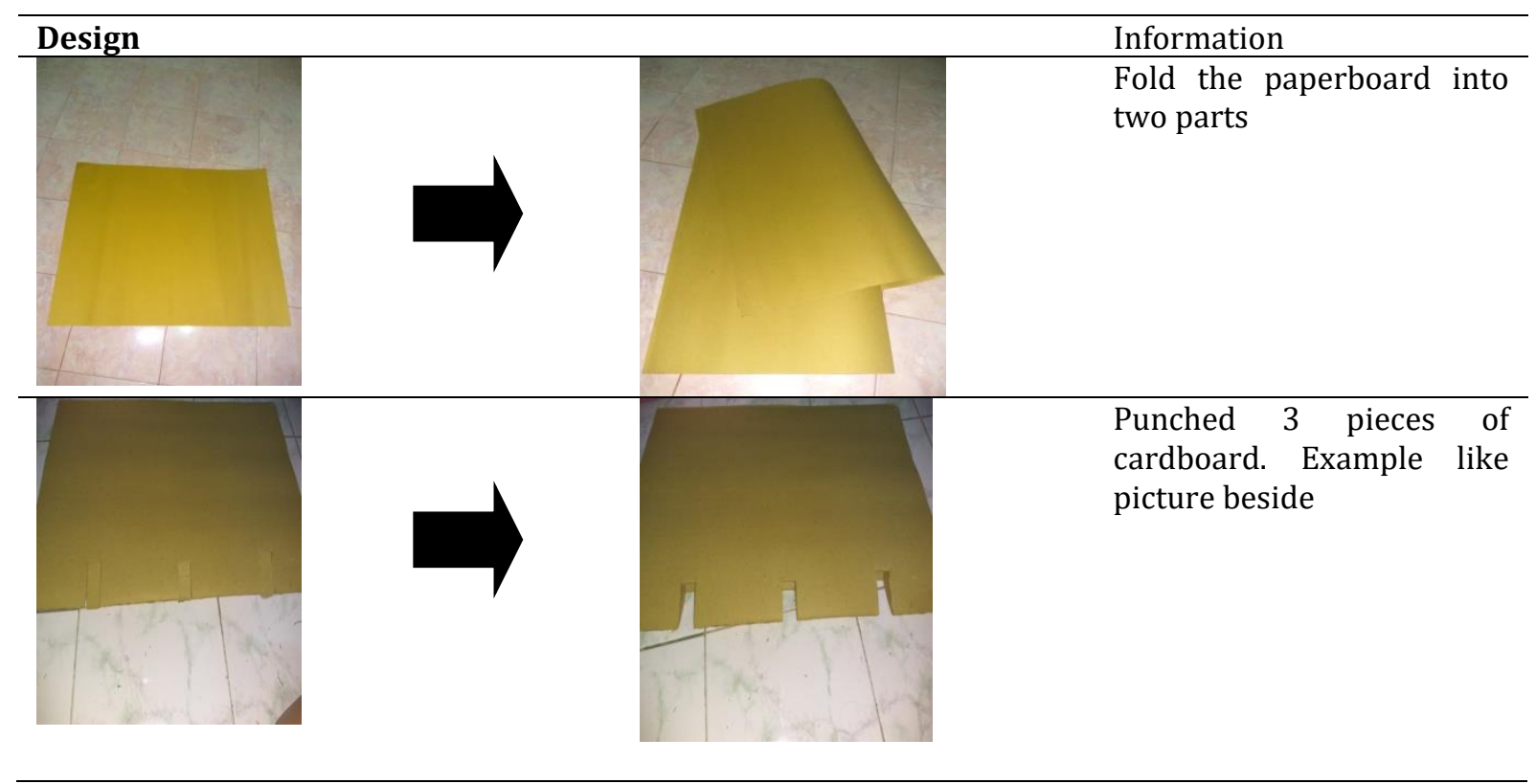




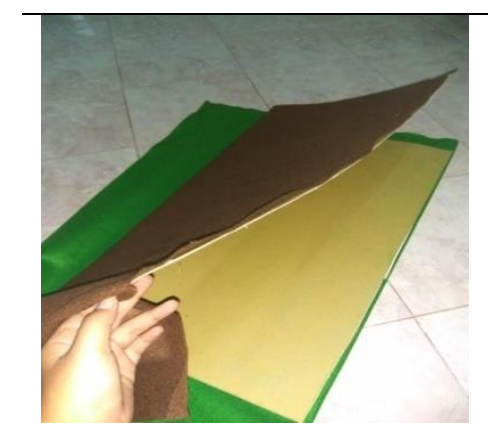

Take the cardboard paper with a flannel cloth using a wax glue

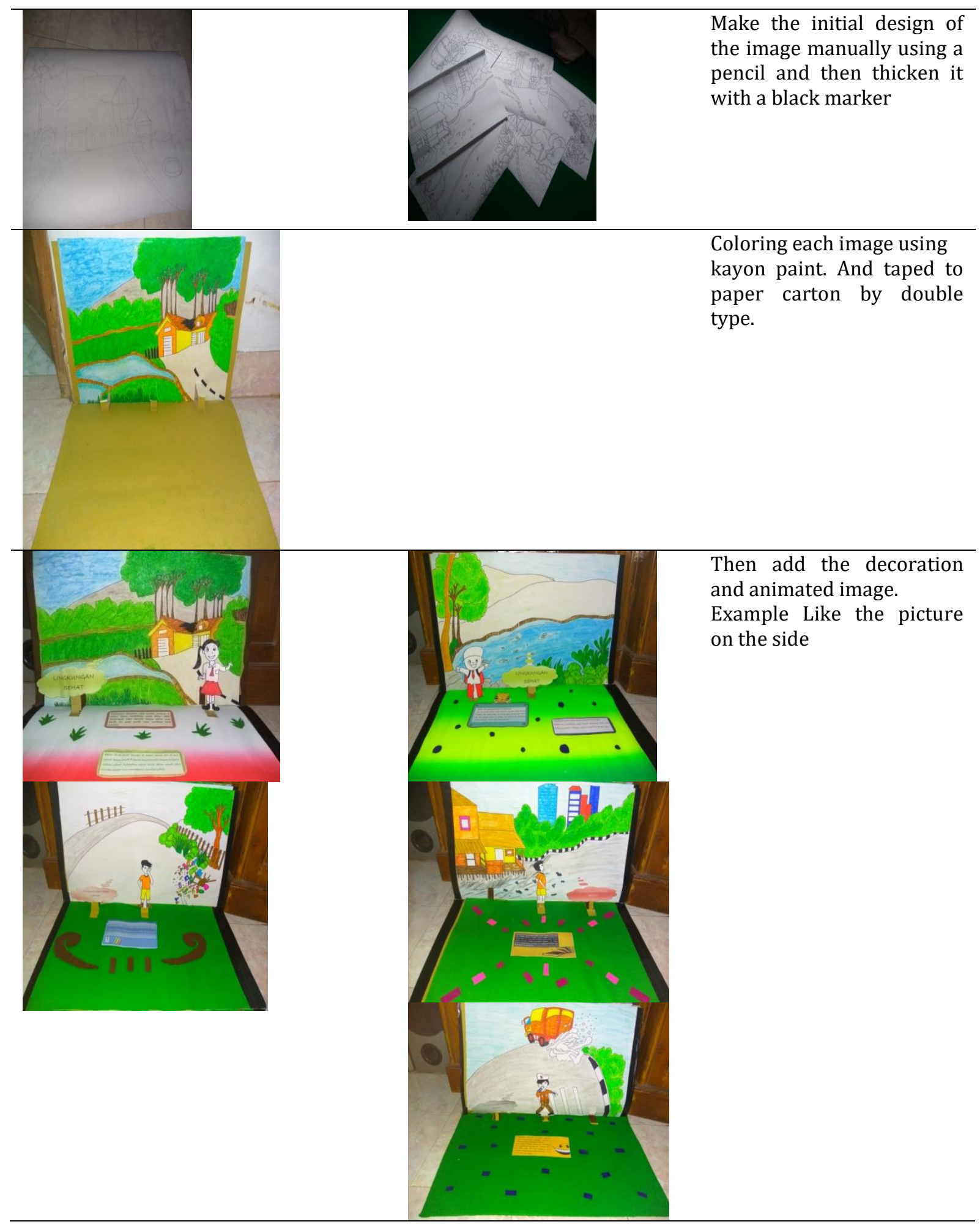




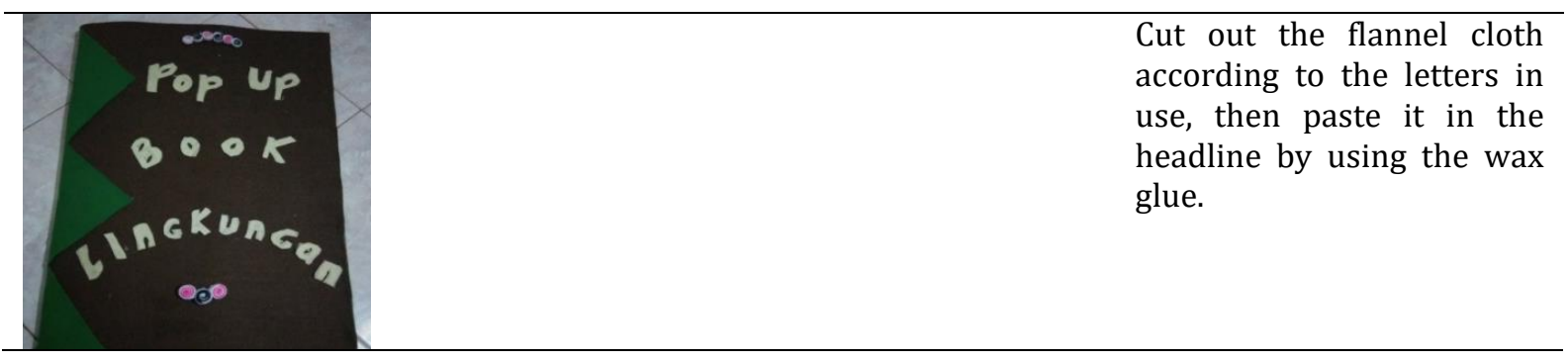

Pop Up Book learning media can help students in understanding the material features of healthy and unhealthy environment. And this pop up book media is only used to distinguish features of healthy and unhealthy environments.

2. Media Principles, Advantages, and Weaknesses

The principle in making this pop up book media is to make students interact directly with the media and provide a real picture of distinguishing features of a healthy and unhealthy environment. Basically, this media is in the form of three dimensions, which when open there is a moving part that can attract students' interest in operating. The advantages of learning media that has been developed is to make students become active in the learning process, flexible because the media can be used anywhere and anytime, generate student motivation, media appearance can attract student interest in learning, able to explain the material in real, which is in the form of three dimensions that if the page in the open can move, and students can directly use this media independently. In addition to the advantages of course there are weaknesses of this media, the weakness of this media is the media can not stand alone, so the media must be in the penggang by the teacher and when placed the media should be given a buffer to stand.

\section{Conclusions and Recommendation}

After doing research, data research results then analyzed, so from the analysis of data can be concluded the results as follows. 1) The development of Pop Up Book media with material distinguishes features of healthy and unhealthy environments based on observation, with the procedure of ADDIE model development that is Analysis, Design, Development, Implementation, Evaluation. 2) Teacher's response to the learning media Pop Up Book developed, after used on learning material characteristics of healthy and unhealthy environment get good response. While the response of students to this media get a positive response, it is seen from the implementation of learning that takes place with the attitude of active students and the results of questionnaires that have been distributed to students. The result of the students' opinion recapitulation on the media obtained the average percentage of answer Yes is $97 \%$ so it can be said that the students are very fond of this media. 3) Feasibility of Pop Up Book media characteristic of healthy and unhealthy environment based on expert material assessment in whole aspect get $87.5 \%$ percentage, media expert assessment $91.2 \%$, grade III teacher assessment SDN Mojoroto 2 90,1\%, and grade 3 of SDN Burengan 2 teacher grade is 95,5\%. This shows that the media of the overall aspect based on the percentage of the feasibility assessment is in the category is very appropriate to be used as learning media of Natural Science for the third grade students of elementary school.

\section{Reference}

Haryono. 2013. Pembelajaran IPA Yang Menarik Dan Mengasyikkan : Teori dan Aplikasi PAIKEM. Yogyakarta: Kepel Press.

Mulyatiningsih, Endang. 2011. Riset Terapan Bidang Pendidikan \& Teknik. Yogyakarta : UNY Press

Permana, Erwin Putera. 2015. Penerapan Metode Problem Solving Dengan Media Gambar Seri Untuk Meningkatkan Hasil Belajar IPS Kelas IV Sekolah Dasar. Jurnal Pendidikan Dasar Nusantara. Vol. (1) No (1). Halaman 25 - 36. http://ojs.unpkediri.ac.id/index.php/pgsd/article/view/152.

Permana, Erwin Putera. 2015. Pengembangan Media Pembelajaran Boneka Kaus Kaki untuk Meningkatkan Keterampilan Berbicara Siswa Kelas II Sekolah Dasar. Jurnal Profesi Pendidikan $\begin{array}{lllllll}\text { Dasar. } & \text { Vol. } & \text { (2) } & \text { No. } & \text { (2). } & \text { Halaman } & 133\end{array}$ 
http://journals.ums.ac.id/index.php/ppd/article/view/1648.

Sugiyono. 2013. Statistik Untuk Penelitian. Bandung: Alfabeta.

Susanto, Ahmad. 2013. Teori Belajar dan Pembelajaran di Sekolah Dasar. Jakarta: Kencana Prenadamedia Group. 